\title{
Importance of Enterococci (Enterococcus faecalis) for Dental Medicine - Microbiological Characterization, Prevalence and Resistance
}

\author{
D. Karayasheva ${ }^{1}$, E. Radeva ${ }^{2}$ \\ ${ }^{1}$ Chief Assistant Professor at the Department of Conservative Dentistry, Faculty of Dental Medicine, Medical University of Sofia, Bulgaria \\ ${ }^{2}$ Associate Professor at the Department of Conservative Dentistry, Faculty of Dental Medicine, Medical University of Sofia, Bulgaria
}

\begin{abstract}
Of all the 19 enterococci species present in genus Enterococcus, E. faecalis is the one that plays the most important role in dentistry. Although initially enterococci were considered to be non-virulent, they are now identified as one of the major causes of nosocomial infections worldwide. They are resistant to most antibiotics and can cause diseases such as periodontitis, peri-implantitis, pharyngitis, otitis, mastoidites, meningitis, endocarditis, urogenital tract infections and even septic conditions. As part of the normal intestinal flora, enterococci, together with $\mathrm{E}$. coli, are used as a sanitary indicator for fecal contamination of drinking water. Of all the 19 enterococci species present in genus Enterococcus, $E$. faecalis is the one that plays the most important role in dentistry. Enterococcus faecalis is associated mostly with persistent infections that are difficult to treat in chronic, apical periodontitis, and recently in periimplantitis also. The assumption that the microorganisms, found in the root canal space, originate from those colonizing saliva and the oral cavity, is widespread. However, the data in the reviewed specialized literature is contradictory.
\end{abstract}

Keywords: enterococci, Enterococcus faecalis, oral bacteria, endodontic infection, endodontic retreatment

\section{Introduction}

Enterococci (genus Enterococcus, former group D streptococci), where E. faecalis and E. faecium belong, are diplococci most commonly found as commensals in the intestinal tract (gastrointestinal carriage), the oral cavity and the urogenital system in humans and animals $(5,40)$. Up to $10 \%$ of the nosocomial infections during the last decade are due to enterococci. Of all the 19 enterococci species present in genus Enterococcus, E. faecalis is the one that plays the most important role in dentistry. Their frequent incidence in foods of animal origin allows for a zoonotic route of transmission of $E$. faecalis to humans $(26,33)$. Transmission of enterococci through meat or raw milk to the human gastrointestinal tract has been suggested by Larsen et al. (2010) and Gelsomino et al. (2002) $(23,32)$.

Studies in recent years have shown that after eating cheese, enterococci from food can be integrated into the oral biofilm, in vivo $(8,11)$, which is confirmed by the in vitro studies of Thurnheer and Belibasakis (62). The finding that E. faecalis from food can be transmitted and find suitable conditions for development in the oral biofilm, raises the question as to whether the oral cavity serves as a reservoir for virulent and resistant $E$. faecalis strains $(7,8)$.

\section{Biology and virulence}

Enterococcus faecalis are Gram-positive cocci or ellipsoid microorganisms arranged in pairs or short chains, morphologically similar to Streptococcus pneumoniae. They grow in the temperature range of $10^{\circ} \mathrm{C}-45^{\circ} \mathrm{C}$ and propagate in a broth containing medium with $\mathrm{pH}=9.6$, and also in such that contains $6.5 \% \mathrm{NaCl}$ or $40 \%$ bile (5). The have a cell wall with a group-specific antigen - group D glycerol teichoic acid. Their virulence is determined by their ability to athere to host surfaces and form biofilms, as well as by their high antibiotic resistance (40).

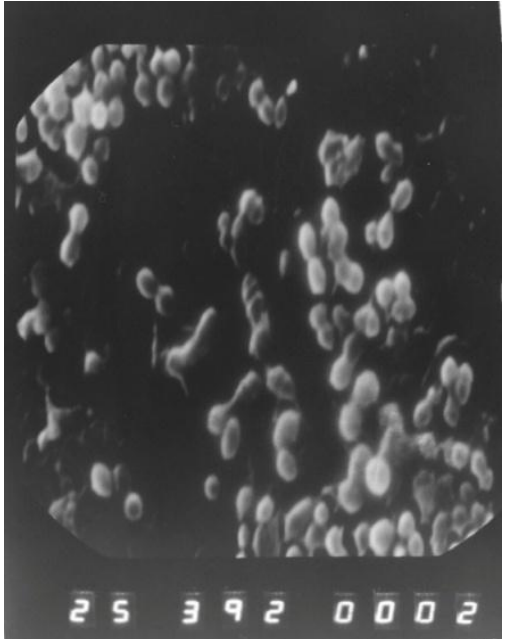

Figure 1: Enterococcus faecalis infected root canal dentin $($ magnification $\times 2420)(4)$

Several virulence factors have been found to increase the capability of specific E. faecalis strains to cause a disease or worsen disease symptoms. It is known that the enterococcal surface protein (esp) increases adherence and colonization of cells and abiotic surfaces $(43,63)$.

Gelatinase ( $\mathrm{gelE}$ ) is an extracellular metalloprotease, able to hydrolyze gelatin, collagen and hemoglobin, which has been reported to also contribute to the bacterial adherence and biofilm formation $(22,29)$. The aggregate substance $(A S)$ was also found to be involved in the microbial attachment and invasion of eukaryotic cells $(31,41,61)$, as well as to contribute to biofilm formation (15).

Hyaluronidase (hyl) has been associated with virulence of enterococci in host tissue invasion $(19,29)$. It is also believed that the E. faecalis endocarditis antigen $A$ (efaA) contributes to the adhesion of $E$. faecalis to heart cells in 


\section{International Journal of Science and Research (IJSR) ISSN (Online): 2319-7064}

Index Copernicus Value (2015): 78.96 | Impact Factor (2015): 6.391

endocarditis (55). And finally, cytolysin (cyl, betahemolysin) is a potent bacteriocin that exacerbates enterococcal infections in humans (64). It is capable of lysing many prokaryotic cells, as well as erythrocytes and other eukaryotic cells (65).

Besides the usual presence of various virulence and resistance genes, E. faecalis is highly proficient in the exchange and passing on of many of these genes through a horizontal gene transfer $(36,43)$. Over the past decade, a transfer of antibiotic-resistance genes between different strains of E. faecium as well as a transfer of vancomycinresistance genes from E. faecalis to Staphylococcus aureus have been reported $(34,44,71)$.

Their frequent incidence in food and livestock could allow for a zoonotic route of transmission of E. faecalis to humans $(26,33)$. The transmission of E. faecalis from meat products of porcine origin or from raw milk to the human gastrointestinal tract has been suggested by Larsen et al. (2010) и Gelsomino et al. (2002) $(23,32)$.

Other authors have demonstrated that after eating cheese, food-borne enterococci can integrate into the oral biofilm in vivo (8), and recently Thurnheer and Belibasakis (2015) confirmed that E. faecalis is able to colonize an in vitro established six-species oral biofilm in high numbers (62). The scientific results showing that E. faecalis from food can incorporate into the oral biofilm and is prevalent in dental endodontic disorders, raises the question as to whether the oral cavity and saliva may serve as a reservoir for virulent and resistant E. faecalis strains $(7,8)$.

\section{Characteristics of cultures/Diagnostics}

Microorganism identification methods using cultures allow for the bacterial susceptibility to antimicrobial agents antibiotics - to be determined, and an antibiogram to be made. The drawbacks of these methods are connected with the detection of low levels of microorganisms and the difficulty to cultivate some species. Diagnosing always starts with a microscope examination of Gram-stained preparations, with crystal-violet. Enterococci are Grampositive and cannot be clearly differentiated from Streptococcus pneumoniae on microscope preparations. If cocci are present in the Gram preparation and there is no growth in the plating, the presence of anaerobic cocci should be suspected (2). Streptococci are in chains on the preparations.

Enterococcus faecalis is easily incubated in ordinary nonselective media, growing under the conditions created for streptococci (2). It develops in the temperature range of $10^{\circ} \mathrm{C}-45^{\circ} \mathrm{C}$ and propagates in a broth containing medium with $\mathrm{pH}=9.6$, and also in such that contains $6.5 \% \mathrm{NaCl}$ (unlike streptococci) or $40 \%$ bile $(2,5)$. It causes a cloudy coloring of liquid nutrient media. In solid media, it grows as smooth, small, protruding, opaque or white colonies with dry consistency (resembling staphylococcal colonies); on blood agars it is non-hemolytic or displays an $\alpha$-hemolysis. Some strains may display a $\beta$-hemolysis. It reduces $0.1 \%$ methylene blue in milk. It hydrolyzes the polysaccharide esculin and is resistant to optochin. E. Faecium is arabinosepositive, and E. faecalis is arabinose-negative (5). It is differentiated from related microorganisms by simple tests: it is catalase-negative; L-pyrrolidonyl arylamidase-positive, bile and optochin resistant $(2,5,40)$. It does not produce exotoxins and hydrolytic enzymes but it produces bacteriocins. It has adhesins - proteins and carbohydrates, with which it colonizes specifically the colon and, less often, the vagina.

\section{Resistance}

Up to $10 \%$ of the nosocomial infections during the last decades are due to enterococci, which is a consequence of the emergence of polyresistant strains to the commonly used antibiotics. Enterococci have natural resistance to cephalosporins, penicillinase-resistant penicillins and monobactams. They are 10 to 1000 times less susceptible to penicillin and ampicillin than streptococci (2). They may show susceptibility to sulfonamides in vitro, and are not susceptible in vivo. The usual concentrations of antibiotics behave towards them as bacteriostatical agents, not as bactericidal agents. For this reason, it is recommended to use a combination of penicillin (ampicillin or vancomycin) and aminoglycoside in the treatment of acute enterococcal infections. The therapy is best to be based on the antibiogram data. $\beta$-lactam-, aminoglycoside- and vancomycin-resistant strains represent a serious problem. Resistance is plasmidinduced and can be transmitted to $S$. aureus $(2,5)$.

Radeva et al. (2012) investigated the antimicrobial resistance of Enterococcus faecalis isolated from infected root canals (4). The results show $100 \%$ resistance to penicillins and $75 \%$ to ampicillin. In $87.5 \%$, enterococci are resistant to amoxicillin/clavulanic acid. In the study carried out, enterococci retained their susceptibility to glycopeptides to $100 \%$ (vancomycin, teicoplanin). Clinical isolates were sensitive to gentamycin to $68.9 \%$ and a high level of resistance to aminoglycosides was not established (Kanamycin) (4).

\section{Disorders}

Enterococcus faecalis colonizes the gastrointestinal tract in humans and animals. It is spreads on other mucosal surfaces also if a prior application of broad spectrum antibiotics has eliminated the normal local microflora. The structure of its cell wall, which is typical of gram-positive bacteria, allows it to survive on surrounding surfaces for prolonged periods of time.

Most of the infections, which they cause, are endogenous (from the patient's own intestinal microflora), but they can also be exogenous, and some are due to patient-to-patient transmission. Diseases include urinary tract infections, peritonitis (usually polymicrobic), wound infections, and bacteremia with or without endocarditis. Patients with an increased risk of developing a nosocomial infection from Enterococcus faecalis are those who are hospitalized for an extended period of time and are treated with broad-spectrum antibiotics (especially cephalosporins to which enterococci are naturally resistant) $(2,40)$. They can cause sepsis in patients with urethral and intravenous catheters. In newborns, they can cause meningitis (2).

\section{Volume 6 Issue 7, July 2017 www.ijsr.net}




\section{International Journal of Science and Research (IJSR) \\ ISSN (Online): 2319-7064}

Index Copernicus Value (2015): 78.96 | Impact Factor (2015): 6.391

\section{The role of Enterococcus faecalis for endodontic infections}

The role of Enterococcus faecalis in the oral cavity has not yet been elucidated. Enterococcus faecalis, although not usually considered to be part of the normal oral microflora $(6,52,68)$, has been found in common dental diseases such as: periodontitis, periimplantitis and dental caries (16, 20, 30, 47). Enterococcus faecalis has been found primarily in secondary endodontic infections with a prevalence of $24 \%$ to $70 \%$, that is, in previously filled root canals, where it can also form a biofilm $(9,10,24,35,38,48,58,67)$. The presence of Enterococcus faecalis is associated with both a primary and a persistent endodontic infection. Enterococcus faecalis is isolated in $10 \%$ of the cases of a primary endodontic infection. According to some authors' investigations, it is more often found in asymptomatic cases than in symptomatic cases $(21,49,57,59)$ Other studies have shown that Enterococcus faecalis is more often isolated in teeth with failed treatment within the range of between $30 \%$ and $90 \%(45,49,60)$. In many of the studies, culture methods for isolation of enterococci were used, and in these cases the isolates were $24 \%-70 \%$. Using a PCR results in a higher isolation rate of $67 \%-77 \%$ (37).

In the oral cavity, with respect to dental pulp diseases, the path of infection penetration is important for the type of the predominant bacterial strains in the infected root canal. Dental pulp can be irreversibly impaired most often through a carious lesion, through an open pulp in a trauma or fracture, through micro cracks, through lateral root canals, after a tooth preparation and restoration (toxic effects of the medications and materials used) as well as through defects in these restorations $(13,18,28,69)$. The microbial count of bacterial cells in an infected root canal is from $10^{3}$ to $10^{8}$ CFU $(50,66)$. When the endodontic space communicates with the oral cavity, the number of bacteria involved in the pathological processes in the endodontium increases. This why it is important not to leave the pulp chamber open in order to avoid the greater invasion by bacteria. The opened endodontium may cause a delay in the healing process in the periapex, which is not beneficial to the healing process.

The bacterial penetration in the dentin is proven in the presence of a pulp necrosis. Bacteria can very easily enter the necrotic pulp because of a lack of protective factors in the root canal also. Predentin is usually more easily infected, whereas calcified dentin makes this more difficult. Colonized microorganisms along the root canal wall often penetrate into the dentinal tubules - from $150 \mu \mathrm{m}$ to 300 $700 \mu \mathrm{m}$. The maximum penetration depth of $S$. sanguis and E. faecalis is $880 \mu \mathrm{m}$ and $770 \mu \mathrm{m}$ after a 60 day incubation (1). When Enterococcus faecalis invades the micro-channel system of the dentin, it becomes difficult to treat and after the other microbes are removed, it seems to be making use of the possibilities to grow in a nutrient-poor environment such as the environment of the treated canal (35). Because of these features, E. faecalis is a microorganism commonly used in in vitro studies. E. faecalis fulfills the necessary conditions for pathogenicity of the microorganisms, which are the following for the endodontic conditions:

- They must be present in a sufficient quantity in order to initiate a periapical inflammation;
- They must possess great virulence;

- They should be located in the space of the root canal system in such a way as to be able to gain access to the periapical tissues.

The root canal environment allows the survival and growth of microorganisms (oxy-reduction processes are greatly reduced or absent and the environment is poor in oxygen) $(28,56,70)$.

Enterococci are difficult to remove after root canal preparation and medication.

A number of authors have examined the effect of chlorhexidine as an endodontic irrigant and an intracanal medicament against E. faecalis and have found that it has an antibacterial activity comparable to that of $\mathrm{NaOCl}$ and is effective against some calcium hydroxide resistant strains $(14,25,46,53,54)$. In our previous in vitro studies on the effectiveness of intracanal medicaments against $E$. faecalis, chlorhexidine showed slightly higher values of antibacterial activity compared to sodium hypochlorite (3). Other authors have also demonstrated in in vitro studies a higher antimicrobial activity of chlorhexidine compared to sodium hypochlorite in the treatment of E. faecalis $(42,53)$.

In a clinical study, Ercan et al. (2004) found that $2 \%$ chlorhexidine was more effective as an endodontic irrigant than $5.25 \%$ sodium hypochlorite (17). In our in vitro studies, using an agar-diffusion method, chlorhexidine showed a slightly higher antimicrobial activity compared to sodium hypochlorite (4).

\section{Conclusion}

The two species, Enterococcus faecalis and Enterococcus faecium, the first being the predominant one, have gained importance in the recent decades as leading opportunistic pathogens causing nosocomial infections $(26,27,39,65)$. They are associated with various infections, including urinary tract infections, bacteraemia, meningitis, wound infections and neonatal infections. More recently, biofilmassociated infections from artificial medical devices have been attributed to enterococci $(12,43,51)$. These are difficult to treat due to their increased antibiotic resistance. Several virulence factors have been found to increase the capability of specific Enterococcus faecalis strains to cause a disease or worsen the disease symptoms. These and other facts explain and justify why Enterococcus faecalis is an interesting subject for future studies by specialists.

\section{References}

[1] Kalchinov, V., S. Dimitrov. Ендодонтска микрофлора - чувствителност и резистентност към медикаментозни средства, съвременни възможности за повлияване. Дентална медицина, 92, 2010, 2, 131 139. (Endodontic microflora - sensibility and resistance towards antimicrobial agents, modern ability to be influenced, Dental Medicine, 92, 2010, 2, 131-139.)

[2] Mitov , G. et al. Микробиология, 2000 г., София, Мед. Издателство „АРСО”, Второ издание, 296-297. 


\section{International Journal of Science and Research (IJSR) \\ ISSN (Online): 2319-7064}

Index Copernicus Value (2015): 78.96 | Impact Factor (2015): 6.391

(Microbiology, 2000, Sofia, Medical Publishing House "ARSO", Second Edition, 296-297.)

[3] Radeva, E., B. Indjov, R. Vacheva. Антибактериална активност на интраканални медикаменти срещу $E$. faecalis (in vitro изследване). Зъболекарски преглед, 87, 2005, 2, 99-103. (Antibacterial activity of intracanal medicaments against E. faecalis (an in vitro study), 87, 2005, 2, 99-103.)

[4] Radeva, E. Терапевтично повлияване на микрофлората и болката при остьр апикален периодонтит-начална форма, без клинични данни за ексудация в кореновия канал. Дисертация, София, 2012. (Therapeutic treatment of microflora and pain in initial phase of acute apical periodontitis, without clinical data for exudation in the root canal, Dissertation, Sofia, 2012.)

[5] Haidushka, I. et al. Медицинска микробиология, 2016, Пловдив, Изд. Лакс Бук, Трето издание, 136. (Medical Microbiology, 2016, Plovdiv, Ed. Lax Book Publishing House, Third Edition, 136.)

[6] Aas, J.A., Paster, B.J., Stokes, L.N., Olsen, I., Dewhirst, F.E. Defining the normal bacterial flora of the oral cavity. J. Clin. Microbiol., 2005, 43, 5721-5732.

[7] Al-Ahmad, A., Muller, N., Wiedmann-Al-Ahmad, M., Sava, I., Hubner, J., Follo, M., et al. Endodontic and salivary isolates of Enterococcus faecalis integrate into biofilm from human salivary bacteria cultivated in vitro. J. Endod., 2009, 35, 986-991.

[8] Al-Ahmad, A., Maier, J., Follo, M., Spitzmuller, B., Wittmer, A., Hellwig, E., et al. Food-borne enterococci integrate into oral biofilm: an in vivo study. J. Endod., 2010, 36, 1812-1819.

[9] Al-Ahmad, A., Ameen, H., Pelz, K., Karygianni, L., Wittmer, A., Anderson, A.C., et al. Antibiotic resistance and capacity for biofilm formation of different bacteria isolated from endodontic infections associated with root-filled teeth. J. Endod., 2014, 40, 223-230.

[10] Anderson, A.C., Al-Ahmad, A., Elamin, F., Jonas, D., Mirghani, Y., Schilhabel, M., et al. Comparison of the bacterial composition and structure in symptomatic and asymptomatic endodontic infections associated with root-filled teeth using pyrosequencing. PLoS ONE, 2013, 8:e84960

[11] Anderson, A.C. et al. Enterococcus faecalis from Food, Clinical Specimens, and Oral Sites: Prevalence of Virulence Factors in Association with Biofilm Formation., Front Microbiol, 2016, Jan 11; 6: 1534.

[12] Arias-Moliz, M. T., Baca, P., Ordonez-Becerra, S., Gonzalez-Rodriguez, M. P., Ferrer-Luque, C. M. Eradication of enterococci biofilms by lactic acid alone and combined with chlorhexidine and cetrimide. Med. Oral Patol. Oral Cir. Bucal, 2012, 17, 902-906.

[13] Ayhan, H., Sultan N., Cirak M., Ruhi M. Z., Bodur H. Antimicrobial effects of various endodontic irrigants on selected microorganisms. Int. Endod. J., 32, 1999, 3, 99102.

[14] Basrani, B. et al. Efficacy of chlorhexidine-and calcium hydroxide containing medicaments against $\mathrm{E}$. faecalis in vitro. Oral Surg., Oral Med., Oral Pathol., Oral Rad. and Endodontology, 96, 2003, 618-624.

[15] Chuang-Smith, O.N. et al. Acceleration of Enterococcus faecalis biofilm formation by aggregation substance expression in an ex vivo model of cardiac valve colonization., 2010, PLos ONE 5: e15798.doi: 10.1371/journal.pone.0015798.

[16]Dahlen G., Blomqvist S., Almstahl A., Carlen A. Virulence factors and antibiotic susceptibility in enterococci isolated from oral mucosal and deep infections. J. Oral Microbiol., 2012, 4:10855.

[17] Ercan, E. et al. Antibacterial activity of $2 \%$ chlorchexidine gluconate and $5,25 \%$ sodium hypochlorite in infected root canal: in vivo study. JOE, 30, 2004, 84-87.

[18] Estrela, C. et al. Mechanism of Action of Sodium Hypochlorite. Braz Dent J, 13, 2002, 2, 113-117.

[19] Fisher, K., Phillips, C. The ecology, epidemiology and virulenceof Enterococcus. Microbiology, 2009, 155, 1749-1757.

[20] Flanagan, D. Enterococcus faecalis and Dental Implants. Journal Oral Imlantoligy, 2017; 43 (1): 8-11.

[21]Fouad A. Endodontic microbiology. 2009, WileyBlackwell.

[22]Franz, C.M., Stiles, M.E., Schleifer, K.H., and Holzapfel, W.H. Enterococci in foods-a conundrum for food safety. Int J. Food Microbiol., 2003, 88, 105-122.

[23] Gelsomino, R., Vancanneyt, M., Cogan, T. M., Condon, S., Swings, J. Source of enterococci in a farmhouse rawmilk cheese. Appl. Environ. Microbiol., 2002, 68, 3560-3565.

[24] Gomes, B. et al. Microbial analysis of canals of rootfilled teeth with periapical lesions using polymerase chain reaction. JOE, 34, 2008, 5, 537-540.

[25] Haenni, S. et al. Chemical and Antimicrobial properties of calcium hydroxide mixed irrigating solutions. Int. Endod. J., 36, 2003, 100-105.

[26] Hammerum, A. M. Enterococci of animal origin and their significance for public health. Clin. Microbiol. Infect., 2012, 18, 619-625.

[27] Hidron, A. I., Edwards J. R., Patel J., Horan T. C., Sievert D. M., Pollock D. A., et al. NHSN annual update: antimicrobial-resistant pathogens associated with healthcare-associated infections: annual summary of data reported to the National Healthcare Safety Network at the Centers for Disease Control and Prevention, 2006-2007. Infect. Control Hosp. Epidemiol., 2008, 29, 996-1011.

[28] Ingle, J., Bakland, L. Endodontics. 5 ed. 2002, BC Decker Inc. Hamilton. London, 67-74.

[29] Kayaoglu, G., Orstavik, D. Virulence factors of Enterococcus faecalis: relationship to endodontic disease. Crit Rev Oral Biol Med. 2004; 15 5:308-320.

[30] Kouidhi, B., Zmantar, T., Mahdouani, K., Hentati, H., Bakhrouf, A. Antibiotic resistance and adhesion properties of oral Enterococci associated to dental caries. BMC Microbiol., 2011, 11:155.

[31] Kreft, B., Marre, R., Schramm, U., and Wirth, R. Aggregation substance of Enterococcus faecalis mediates adhesion to cultured renal tubular cells. Infect. Immun., 60, 25-30.

[32] Larsen, J., Schonheyder ,H. C., Lester, C. H., Olsen, S. S., Porsbo L. J., Garcia-Migura L., et al. Porcine-origin gentamicin-resistant Enterococcus faecalis in humans, Denmark. Emerging Infect. Dis., 2010, 16, 682-684.

[33] Larsen, J., Schonheyder, H. C., Singh, K. V., Lester, C. H., Olsen, S. S., Porsbo, L. J., et al. Porcine and human

\section{Volume 6 Issue 7, July 2017 www.ijsr.net}




\section{International Journal of Science and Research (IJSR) \\ ISSN (Online): 2319-7064}

Index Copernicus Value (2015): 78.96 | Impact Factor (2015): 6.391

community reservoirs of Enterococcus faecalis, Denmark. Emerging Infect. Dis., 2011, 17, 2395-2397.

[34] Lester, C.H. et al. In vivo transfer of the vanA resistance gene from an Enterococcus faecium isolate of animal origin to an E. faecium isolate of human origin in the intestines of human volunteers. Antimicrob. Agents Chemother., 2006, 50, 596-599.

[35] Love, R.M. Enterococcus faecalis - a mechanism for its role in endodontic failure. Int Endod J. 2001; 34 5:399405

[36] Manson, J.M., Hancock, L.E., and Gilmore, M.S. Mechanism of chromosomal transfer of Enterococcus faecalis pathogenicity island, capsule, antimicrobial resistance, and other traits. Proc. Natl. Acad. Sci. U.S.A., 2010, 107, 12269-12274.

[37] Mohammadi Z. Effects of root canal irrigants on the planktonic form of Enterococcus faecalis: A review. Nigerian J of Medicine, 2015, 24(3):261-267.

[38] Molander A., C. Reit, G. Dahlen, T. Kvist. Microbiological status of root- filled teeth with apical periodontitis. Int. Endod.J., 31, 1998, 1-7.

[39] Murray, B. E. The life and times of the Enterococcus. Clin. Microbiol. Rev., 1990, 3, 46-65.

[40] Murray, P.R., Rosental, K.S., Pfaller, A. Medical microbiology. 2016, Elsevier, 8 edition: 183-201.

[41] Olmsted, S.B., Dunny, G.M., Erlandsen, S.L., Wells, C.L. A plasmid-encoded surface protein on Enterococcus faecalis augments its internalization by cultured intestinal epithelial cells. J. Infect. Dis., 1994, 170, 1549-1556.

[42] Oncago et al. Comparison of antibacterial and toxic effects of various root canal irrigants. Int. Endod. J., 36, 2003, 423-432.

[43] Paganelli, F. L., Willems, R. J., Leavis, H. L. Optimizing future treatment of enterococcal infections: attacking the biofilm? Trends Microbiol., 2012, 20, 4049.

[44] Palmer, K.L., Kos, V.N., and Gilmore, M.S. Horizontal gene transfer and the genomics of enterococcal antibiotic resistance. Curr. Opin. Microbiol., 2010, 13, 632-639.

[45] Pinheiro, E. et al Microorganisms from canals of rootfilled teeth with periapical lesions. Int. Endod. J, 36, 2003, 1-11.

[46] Radcliff, C. E. et al. Antimicrobial activity of varying concentrations of sodium hypochlorite on the endodontic microorganisms Actinomyces israeli, A. naeslundi, Candida albicans and $\mathrm{E}$ faecalis. Int. Endod. J., 37, 2004, 438-446.

[47]Rams, T.E., Degener, J.E., van Winkelhoff, A.J. Prevalence of beta-lactamase-producing bacteria in human periodontitis. J. Periodont. Res., 2013, 48, 493499.

[48]Ran, S., Liu, B., Jiang, W., Sun, Z., Liang, J. Transcriptome analysis of Enterococcus faecalis in response to alkaline stress. Front. Microbiol., 2015, 6:795.

[49] Rocas, I. N., Siqueira, J.F., Santos, K.R. Association of Enterococcus faecalis with different forms of periradicular diseases. JOE, 30, 2004, 315-20.

[50] Sakamoto, M., Siqueira, J.F., Rocas, I.N., Benno, Y. Bacterial reduction and persistence after endodontic treatment procedures. Oral Microbiology and Immunology, 22, 2007, 19-23.

[51] Sandoe, J. A., Witherden, I. R., Cove, J. H., Heritage, J., Wilcox, M. H. Correlation between enterococcal biofilm formation in vitro and medical-device-related infection potential in vivo. J. Med. Microbiol., 2003, 52, 547-550.

[52] Sedgley, C.M., Buck, G., Appelbe, O., Prevalence of Enterococcus faecalis at multiple oral sites in endodontic patients using culture and PCR. J Endod. 2006; 32 (2): 104-109.

[53] Sena, N.T. et al. In vitro antimicrobial activity of sodium hypochlorite and chlorhexidine against selected single-species biofilms, Int. Endod. J., 39, 2006, 878885.

[54] Shen, Ya, Stojicic Sonja, Haapasalo M. Antimicrobial efficacy of chlorhexidine against bacteria in biofilms at different stages of development. JOE, 37, 2011.

[55] Singh, K.V. et al. In vivo testing of an Enterococcus faecalis efaA mutant and use of efaA homologs for species identification. FEMS Immunol. Med. Microbiol., 1998, 21, 323-331.

[56] Siqueira, J. F. Strategies to Treat Infected Root Canals. J. of California dental association, 2001.

[57] Siqueira, J. F. et al. Fungal infection of the radicular dentin. J. of Endod., 28, 2002, 11, 770-773.

[58] Siqueira, J. F., Jr., Rocas, I. N. Diversity of endodontic microbiota revisited. J. Dent. Res., 2009, 88, 969-981.

[59] Souto, R, Colombo A. P. Prevalence of Enterococcus faecalis in subgingival biofilm and saliva of subjects with chronic periodontal infection. Arch Oral Biol. 2008, 53 2:155-160.

[60] Sundqvist ,G., Figdor, D. et al. Microbiologic analysis of teeth with failed endodontic treatment and the outcome of conservative re-treatment. Oral Surg., Oral Med., Oral Pathol., Oral Rad. and Endodontology, 85, 1998, 1, 86-93.

[61] Sussmuth, S.D. et al. Aggregation substancepromotes adherence, phagocytosis, and intracellular survival of Enterococcus faecalis within human macrophages and suppresses respiratory burst. Infect. Immun., 2000, 68, 4900-4906.

[62] Thurnheer, T., Belibasakis, G. N. Integration of nonoral bacteria into in vitro oral biofilms., Virulence, 2015, 6, 258-264.

[63] Toledo-Arana, A. et al. The enterococcal surface protein, Esp, is involved in Enterococcus faecalis biofilm formation. Appl. Environ. Microbiol. 67, 45384545.

[64] Van Tyne, D. et al. Structure, function, and biology of the Enterococcus faecalis cytolysin. Toxins (Basel), 2013, 5, 895-911.

[65] Van Tyne, D., Gilmore, M. S. Friend turned foe: evolution of enterococcal virulence and antibiotic resistance. Annu. Rev. Microbiol., 2014, 68, 337-356.

[66] Vianna M. et al. In vivo evaluation of microbial reduction after chemo-mechanical preparation of human root canals containic necrotic pulp tissue. Int. Endod. J., 39, 2006, 484-92.

[67] Vidana, R., Sullivan, A., Billstrom, H., Ahlquist, M. Lund, B. Enterococcus faecalis infection in root canals host-derived or exogenous source? Lett. Appl. Microbiol., 2011, 52, 109-115. 


\section{International Journal of Science and Research (IJSR) \\ ISSN (Online): 2319-7064}

Index Copernicus Value (2015): 78.96 | Impact Factor (2015): 6.391

[68] Wang, Q., Zhang, C., Chu, C, Zhu, X. Prevalence of Enterococcus faecalis in saliva and filled root canals of teeth associated with apical periodontitis. Int $\mathrm{J}$ O Sci. 2012, Apr; 4 (1): 19-23.

[69] Weine F.S. Endodontic therapy., 1989, 4-th ed., St. Louis, Mosby, 370-373.

[70] Weine, F. S. Endodontic therapy. 1996, $5^{\text {th }}$ ed., MosbyYear Book, Inc., St. Louis. Miccrobiology in endodontics, 693-714.

[71] Willems, R.J. et al. Variant esp gene as a marker of a distinct genetic lineageof vancomycin-resistant Enterococcus faecium spreading in hospitals. Lancet, 2001, 357, 853-855.

Volume 6 Issue 7, July 2017 www.ijsr.net 